\title{
Elementary Teacher Education Students' Short Story Writing Skills through Creative Writing Learning for Short Movie Making
}

\author{
Muhammad Rizal Fauzi ${ }^{\otimes_{1}}$ \& D. Fadly Pratama ${ }^{2}$ \\ 1,2 Elementary Teacher Education Department, IKIP Siliwangi, Bandung, Indonesia \\ $\triangle$ fauzi@ikipsiliwangi.ac.id
}

\begin{abstract}
Short story writing skill (short stories) for elementary teacher education students at Cimahi City campus is one of the productive language skills that are said to be still very difficult, considering the skill to write requires multi skills that involve cognitive skills, cognitive meta, experience, imagination, and the preparation of words and sentences accordingly. Hence, this digital era should be able to make students skilled in utilizing digital devices and products as a medium that helps facilitating them in honing their short story writing skills, one of which is through digital products in the form of short movies. The purpose of this research is to know and elaborate the elementary teacher education students' skills to write short stories of through short movie making activities in creative writing. This study employs descriptive qualitative through triangulation of data obtained from observations, tests, questionnaires, and documentation. The results showed the students' skills to write short stories through short movie making activities, it was obtained based on the indicators of short story writing that had been achieved, namely: the suitability of story content, story development creativity, presentation of the plot, characters, point of view, diction, plot, and writing spelling.
\end{abstract}

Keywords: Short Stories, Short Movie, Creative Writing, Writing Skills

How to Cite: Fauzi, M., \& Pratama, D. (2021). Elementary Teacher Education Students' Short Story Writing Skills through Creative Writing Learning for Short Movie Making. Mimbar Sekolah Dasar, 8(1), $96-113$. doi:https://doi.org/10.53400/mimbar-sd.v8i1.26491.

INTRODUCTION The transformation of reading and writing culture is closely aligned with the acceleration of technological development, so that the cultural transformation of reading and writing is not inevitable, slowly changing its presentation into a virtual form that is more easily accessed and understood for readers. A similar statement was expressed by Abidin (2015) that technological developments should be able to change the paradigm of student learning activities, hence, the development of student literacy can be dynamic in line with technological developments.

Seeing the contextual phenomenon today, the motivation to read and write through mainstream devices for students in tertiary institutions tends to decrease; considering that the information media and technology are in great demand used by students as a means of obtaining literature as media to read and write, and even to translate written forms into audio-visuals (movies) to understood better by the readers (Derry, Sherin\& Sherin, 2014). Therefore, the availability of digital media should be a means to develop students' language skills, especially in written form, so they will be more interested in making short story writing as an effort to improve the literacy culture (Eng et al., 2020). 
Muhammad Rizal Fauzi \& D. Fadly Pratama, Elementary Teacher Education Students' Short Story...

Based on data released by the Ministry of Communication and Information Technology (Kominfo), since 2014-2018 Indonesia ranked sixth as the most country in internet usage (Yusuf, 2018). Moreover, it has been predicted that in 2023 Indonesia will get more internet users, considering the increasing number of productive age citizens (Jayani, 2019). This indicates that Indonesia has a great opportunity to use digital media as a media that helps improving the development of literacy culture, one of which is in creative writing learning activities in tertiary institutions. However, this is inversely proportional to the data obtained from the Asia Pacific Nature Publishing Index (Asia Pacific Scientific Journal Publishing Agency) in 2014-2015 Indonesia ranked 12th out of 20 countries in publishing books and scientific papers (Persadha, 2016), meaning that the productivity of writing society in Indonesia, especially in universities was still lacking compared to other developed countries.

Authentically, the problems found during the lecture showed that composing a narrative essay in the form of a short story was found difficult seen from the $60 \%$ short story writing indicator shown by elementary teacher education students in one of campus Cimahi City. They found it difficult to determine the title of a theme, a logical storyline, use diction and sentences accordingly, and lack of a climax component in the storyline. This problem indicates that elementary teacher education students still have difficulties in compiling short stories as a product of literary works in learning creative writing.

To solve this issue, it is necessary to have media that helps students in composing short stories through audio-visual media in the form of short movies. The use of short movie learning media, in general, has been widely developed and applied in various research literature. The results of research conducted by Schneider et al., (2019) showed the effectiveness of the short movie media as one of the digital media that can provide a clear picture of the plot of a story, hence, the presentation of the short movie has implications for the imagination and audio-visual experience representative of the author by the elements contained in the short story. Other research results from Simanungkalit \& Sembiring (2019) explain the difficulty of writing short stories in elementary teacher education students shown by the difficulty in determining the topic and making the framework of the topic divided into short story elements. Another obstacle is shown by the difficulty to use appropriate language for children as the language of instruction in short stories, then the use of video-based media is needed to open students' insights in designing short stories.

In this study, the aspect developed was how students were not only able to make short stories assisted by audio-visual media in the form of short movies, but also to make two products at once, namely making short stories as well as making short movies. From several research results in various countries, the development of short story writing skills and short movie making skills is still not linked. In Mongar \& Chalermnirundorn's (2020) research, the effectiveness of 
digital media in improving the narrative writing skills of Thai high school students was very effective if there is supporting media in the form of animated movie visualization. Through their research, movie can present an element of imagination to students so that it is easy to develop writing skills. Then, another study developed by Kim (2016) at Korea University tested a multimodal approach to short movies that would show communication competence and student reactions through storytelling tasks. The result showed that most students were able to convey the essence of storytelling through English after watching a short movie. From these two previous studies, the use of short movies only has an impact on merely students' cognitive skills. In contrary, in this research, the students were invited to write short stories as a cognitive output, to make them skilled in making short movies as an output of their psychomotor skills.

The purpose of the short movie making activity is only as an introductory activity so that students can understand the story scenario structure contained in the movie made in groups. Therefore, after the movie project is completed, students will easily adapt to the story series that have been acted directly through making short movies. Based on these assumptions, researchers have several reasons why making short stories in learning creative writing should be done through short movie making activities, including: (1) in Piaget's Cognitive theory, students' cognitive skills are in the formal operational phase, making it possible for them to develop imagination even though through things that are considered abstract (Moore et al., 2019; Redifer et al., 2019); (2) Piaget's cognitive theory reveals the process of assimilation in the adult phase being able to creatively process information by integrating new experiences with concepts of knowledge that already exist in mind (Kervin et al., 2017); and (3) digital media mastery opportunities among teenagers are mushrooming, so that the motivation of students' existence makes it possible to create visual works that can be published in social networks, this is evidenced by dozens to dozens of cinematographic works that have been successfully created by students.

The purpose of this study is to determine and elaborate on the short story writing skills of the students of elementary teacher education department through short movie making activities on creative writing learning. Therefore, the activity of making short movie will become a parameter to understand the elements of a short story. The structure in the short story is not sufficiently embodied through theory and mainstream media alone, understanding the intrinsic and extrinsic elements in it must be done through direct involvement of students in playing roles as well as designing the movie itself (Feeney \& Gajaseni, 2020). According to Frith (2020) in his article entitled Teaching in 2020: The impact of neuroscience, the structure of children's brain development will be in line with environmental developments, meaning that the development of student learning in school must always be spurred on by technological developments. Making short stories through short movie is something that is often done in several countries, considering the use of movie media and its production can be effectively 
Muhammad Rizal Fauzi \& D. Fadly Pratama, Elementary Teacher Education Students' Short Story...

integrated with other learning activities, considering that students' will be more motivated to publish the results their work through online media, with the hope that his work can be enjoyed easily (Chaya \& Inpin, 2020).

\section{THEORETICAL FRAMEWORK}

\section{Short Story Creative Writing}

Writing is one of the four most productive language skills, said to be productive because the components in writing activities require multi-skills that involve other language skills such as listening, speaking, and reading (Beiler \& Dewilde, 2020). Besides, the metacognitive process and the experience results obtained are part of the composition that must be present in writing activities because this is the essence of a series of experiences, both from reading and interacting with the environment (Patrick, 2019). In another aspect, writing is said to be a medium of communication between writers and readers in conveying messages both from an event, as well as the result of imagination (fiction), so that readers get information or understanding even invitations from written messages (Ezza et al., 2019). Thus, writing is said to be a fairly complicated process because it involves various cognitive and metacognitive aspects.

In addition to a complex series of activities, writing is a series of skill processes for expressing new ideas, expressing feelings, connecting people to the culture of creation, space, time, and the writer's imagination, so it can be assumed that writing skills are communication activities (Kartika et al., 2018). Based on these assumptions, writing skills can be developed independently by students at every level at school. However, the efforts to develop writing skills should be supported by adequate literature and media. Hence, the students can observe and analyze the organization of ideas, content, or diction that are written well, through the stages of knowing, understanding, analyzing, synthesizing, and evaluating a series of activities that students do (Göçen, 2019; Purba, 2018).

Writing short stories is one of the creative writing skills and one of the literary products that are included in the form of narrative or fantasy essays. Therefore, the process of making it is not easy because writing a short story involves a process of imagination and experience to process intrinsic and extrinsic elements. Therefore, the use of word/diction and sentence composition must be able to convey the purpose and message to the readers; this is often used as part of the students' difficulties in compiling a fiction/non-fiction essay in the short story-making process (Dewi, 2016; Linda, 2017; Feeney \& Gajaseni, 2020). In another sense, writing a short story is a literary product that can convey knowledge or a cultural background image seen from the author's point of view, with this, the important element in the short story is extrinsic so that each writer can convey ideas in line with their distinctive thoughts and cultural background (Rezaei \& Naghibian, 2018). Furthermore, Rodríguez (2017) explained in the results of his research at the University of Santo Tomas Columbia that the implications of 
written learning are able to hone literary skills and understand cultural elements and moral messages in it, so that every reader and writer will not be swept away in the flowing world.

\section{Short Movie}

Movie is an audio-visual media that is able to effectively provide information, explain the process/story line, explain concepts that are considered complicated, and teach skills the sensitivity in obtaining information (Arsyad, 2011). Substantively, the effectiveness of movies in learning activities act as a medium that is able to deliver students 'knowledge and skills on contextual matters and hone students' imagination skills (Köroğlu, 2020). A similar idea was expressed by Rahman (2018) that the nature of learning media, both audio and visual, is able to become a transformative medium in conveying knowledge to students in every learning process.

Short movie is a type of movie production that describes a problem that is briefly presented but gives an impression and message to the viewer (Kabadayi, 2012). According to this statement, short movies can provide reflection for educators and students through their impact on students' cognitive and affective knowledge, because basically the affective domain is able to accept the rational learning process, so that the concept of understanding in learning is easy to remember because it can give an impression to students (Blasco et al., 2015).

When short movies are implemented in learning activities at school, the media can have a big influence on students' critical thinking skills since the elements in the media are able to give a visual picture through case studies shown in good acting scenes about life problems, differences. culture, perspective, and problem solving (Galante, 2015). In addition to improving critical thinking skills, short movie when implemented in learning activities in schools lead the students to have skills in analyzing short story texts that are integrated with the short movie experience visually, hence, short movies have a great opportunity to be used as a medium that is able to stimulate skilled students in making a short story (Liao, 2020).

\section{METHOD}

\section{Research Design}

This study employs descriptive qualitative analysis of data obtained through data triangulation comparisons. Data triangulation is designed to provide confidence to researchers about the validity of the data obtained so that it will facilitate researchers in providing research conclusions (Bachri, 2010). According to Creswell (2014), qualitative research is research based on post positivism theory, which is used to observe and analyze all processes naturally through integration and comparison between triangulation of data done by prioritizing meaning rather than generalization. In line with these statements, Arikunto 
Muhammad Rizal Fauzi \& D. Fadly Pratama, Elementary Teacher Education Students' Short Story...

(2013) explained that qualitative descriptive research aims to obtain a picture of the phenomena that occur, then analyze and elaborate the phenomena in-depth.

The data collection technique was obtained through three designed instruments, namely observation, tests and questionnaires, which was done in six months. The documentation is used as reinforcement to confirm the results of the research activities carried out. The subjects in this study were two classes of sixth semester elementary teacher education students of a university in West Java, Indonesia.

\section{Research Participants}

The participants were the 6th-semester elementary teacher education students in one of the Cimahi City universities. It was carried out in two classes, consisting of class A totaling 42 people, and class B totaling 38 people with an average of coming from Cimahi City and Bandung Regency. The reason for choosing students from two class because the researchers assumed there were some similarities such as 1) the similarity of the study program, namely primary school teacher education, 2) being of the same age, namely 19 years old on average, 3) the economy background of students from middle-class families and above, 4) students' reading and writing skills are high based on the cognitive levels and language development, and 5) are in the same course, namely Indonesian Language and Literature.

\section{Research Procedure}

The procedure or steps taken in this qualitative descriptive study were adapted from (Sugiyono, 2015), as follows: (1) Preparing and determining research subjects; (2) Doing observations. Observations were made in creative writing learning through short stories and short stories written by students developed from learning instrument and the short assessment rubric; (3) Testing. The test was a written test carried out by each individual, then adjusted to a particular grading rubric; (4) Filling out the questionnaire. The questionnaire presented is a statement using a Likert Scale. The questionnaire was given to all respondents and filled out online; (5) Collecting and processing data (data reduction); (6) Analyzing data. Data analysis was performed qualitatively through searching for equations and comparing patterns, models, and themes from the data obtained; and (7) Describing and interpreting data; and (8) Drawing conclusion.

\section{RESULTS}

The results obtained from this study refer to the data collected from observations, written tests, questionnaires, and documentation, which were then analyzed by linking various data and comparing them, if necessary, the reduction of data processing results.

Observation Results of Elementary Teacher Education Students' Shirt Story Skills through Short Movie Making Activities 
Observations on short story writing activities through short moviemaking activities were carried out through group activities in one month from the 2nd to 4th meetings, in which the last meeting of the observations was done online due to COVID-19 pandemic. Online observations were done by observing the results of the students' short story writing so that the observation process in the second month was carried out through test activities, which resulted in the following data:

Table 1. Observation Results of Elementary Teacher Education Students' Short Story Writing through Making Short Movies

\begin{tabular}{|c|c|c|c|}
\hline \multirow[t]{2}{*}{ No } & \multirow[t]{2}{*}{ Short Story Writing Activities } & \multicolumn{2}{|c|}{$\begin{array}{c}\text { Implementation in the } \\
\text { Meeting }\end{array}$} \\
\hline & & 1 & 2 \\
\hline 1. & Observing Short Movies of group work & $\checkmark$ & $\checkmark$ \\
\hline 2. & Observing the elements contained in the short movie & $\checkmark$ & $\checkmark$ \\
\hline 3. & Discussing short movie elements & $\checkmark$ & $\checkmark$ \\
\hline 4. & Integrating short movie elements with short story elements & & \\
\hline 5. & $\begin{array}{l}\text { Determining the theme of the short story that will be } \\
\text { created }\end{array}$ & $\checkmark$ & $\checkmark$ \\
\hline 6. & $\begin{array}{l}\text { Determining the title of the short story that matches the } \\
\text { theme }\end{array}$ & & $\checkmark$ \\
\hline 7. & $\begin{array}{l}\text { Designing the short story structure of the short movie } \\
\text { observation process }\end{array}$ & & \\
\hline 8. & Determining the story line in the short story & & $\checkmark$ \\
\hline 9. & Determining the setting or place on the short story & $\checkmark$ & $\checkmark$ \\
\hline 10. & Determining the character in the short story & $\checkmark$ & $\checkmark$ \\
\hline 11. & Determining the character / character of each character & $\checkmark$ & $\checkmark$ \\
\hline 12. & $\begin{array}{l}\text { Determining the selection of diction that is appropriate to } \\
\text { the child's language }\end{array}$ & $\checkmark$ & $\checkmark$ \\
\hline 14. & $\begin{array}{l}\text { Determining the spelling and reading according to } \mathrm{EBI} \text { and } \\
\text { short story characters }\end{array}$ & & \\
\hline 15. & Determining the message contained in the short story & $\checkmark$ & $\checkmark$ \\
\hline & Score & 9 & 10 \\
\hline & Percentage & $60 \%$ & $73.3 \%$ \\
\hline
\end{tabular}

The instrument was adapted and modified from Nurgiyantoro (2013) and Kervin et al., (2017)

Table 1 above presents that learning to write short stories through making short movies in the first meeting showed a percentage of $60 \%$. The implementation was to carry out observations on the movie of each group's work, observe the elements of the story in the short movie, discuss the elements of the story in the short movie with the group, determine the theme, 
Muhammad Rizal Fauzi \& D. Fadly Pratama, Elementary Teacher Education Students' Short Story...

determine the setting, character, use diction for children's short stories, and message of the short stories. While other points have not yet been implemented including:

1. Integrating the elements of a short movie with a short story. Most students determine the short story element based on the principle of preparing a short story, meaning that the student's analytical skills were still not sensitive at the first meeting.

2. Making short story title based on the theme. Most students were found not able to make an interesting title.

3. Have not designed the structure of a short story completely from the observation of a short movie due to different movie structure and the short story, resulted in students' confusion.

4. Determining the storyline in the short story. Students' story line was not logical, their climax and anti-climax tended to be less well-structured.

5. The use of grammar based on General Indonesian Spelling Guidelines (PUEBI, Panduan Umum Ejaan Bahasa Indonesia). The students were still confused about the use of punctuation, capital letters, affixes, and prepositions.

The second meeting showed a percentage of $73.3 \%$ of implementation of short story learning activities. The students performed a little improvement, namely observing the movie work of each group, observing the elements of the story in the short movie, discussing the elements of the story in the short movie with the group, being able to carry out the determination of the theme, determining the title, determining the setting, character, use of dictionaries for children's short stories, and message of the short stories. Meanwhile, the other points that have not yet been implemented including:

1. Integrating the elements of a short movie with a short story. Most students determined the short story element based on the principle of preparing a short story, meaning that the student's analytical skills were still not sensitive at the first meeting.

2. Designing the structure of a short story. From observation, it was seen that students were confused because of different structures of the movie and short story.

3. The use of grammar based on PUEBI. The students' writing still contained errors such in the use of punctuation, capital letters, and affixes.

An increase in this implementation is not the main goal of the research, but in the learning activity to achieve success of learning where students' understanding the concept of writing short stories through short movie making activities is increasing.

\section{Short Story Writing Skills Test of Elementary Teacher Education Students through Short Movie Making Activities}

The results of this test are the second parameter that shows the skills to write short stories after making short movies. The test was conducted on the work of individual student short stories, 
after going through the process of making and observing short movies from each group. The rating refers to the short story writing rubric which is determined according to the indicators of short story writing skills. The test result is presented in Table 2 below.

Table 2. Results of Short Story Writing Test of Elementary Teacher Education Students through Making Short Movies

\begin{tabular}{|c|c|c|c|c|c|c|c|c|c|c|c|c|}
\hline \multirow[b]{4}{*}{ No } & \multirow{4}{*}{ 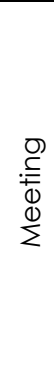 } & \multicolumn{10}{|c|}{ Short Story Aspects } & \multirow{4}{*}{$\begin{array}{l}\stackrel{D}{a} \\
\mathbb{D} \\
\stackrel{0}{Q} \\
\mathbb{Q} \\
\mathbb{D} \\
\tilde{ก} \\
0 \\
\frac{0}{D}\end{array}$} \\
\hline & & \multicolumn{2}{|c|}{ Fill Short Stories } & \multicolumn{3}{|c|}{$\begin{array}{c}\text { Short Story Presentation } \\
\text { Elements }\end{array}$} & \multicolumn{3}{|c|}{ Mood Story } & \multicolumn{2}{|c|}{$\begin{array}{c}\text { Writing } \\
\text { Procedure }\end{array}$} & \\
\hline & & \multicolumn{10}{|c|}{ Short Story Writing Indicator } & \\
\hline & & 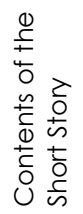 & 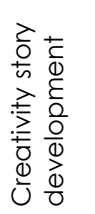 & 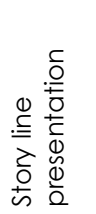 & 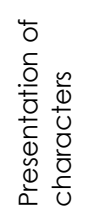 & 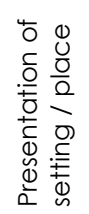 & 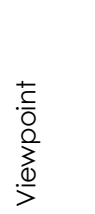 & 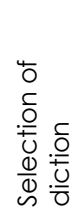 & 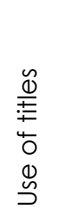 & 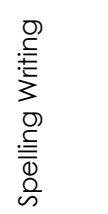 & 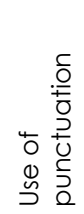 & \\
\hline 1. & \multirow[b]{2}{*}{ III } & 3.0 & 2.5 & 2.7 & 3.7 & 3.5 & 2.5 & 2.5 & 3.2 & 2.3 & 2.8 & \multirow[b]{2}{*}{71.5} \\
\hline$\%$ & & $75 \%$ & $62 \%$ & $68 \%$ & $93 \%$ & $88 \%$ & $61 \%$ & $63 \%$ & $81 \%$ & $57 \%$ & $69 \%$ & \\
\hline 2. & \multirow{2}{*}{ IV } & 3.3 & 2.9 & 3.2 & 3.9 & 3.6 & 2.7 & 2.8 & 3.6 & 2.6 & 2.9 & \multirow{3}{*}{78} \\
\hline$\%$ & & $81 \%$ & $72 \%$ & $79 \%$ & $96 \%$ & $90 \%$ & $68 \%$ & $69 \%$ & $89 \%$ & $64 \%$ & $73 \%$ & \\
\hline & & $78 \%$ & $67 \%$ & $73.5 \%$ & $94.5 \%$ & $89 \%$ & $64.5 \%$ & $66 \%$ & $85 \%$ & $60.5 \%$ & $71 \%$ & \\
\hline
\end{tabular}

Table 2 presents students' increasing skills in writing short stories. The increase was seen based on 10 short story writing done in the third and fourth meetings. The scores obtained in each indicator were determined based on the average score obtained from all 83 students. The assessment rubric is set as the rating standard for each indicator of writing short stories with categories 4 = very well, $3=$ good, $2=$ moderate, and $1=$ less. The increasing skills of short story writing indicator is elaborated below:

The suitability of the story content with the theme. In the third meeting, the average percentage of students earned $75 \%$, and in the 4 th meeting, the score was $81 \%$. This means that the students were able to make the story content by the theme. Nevertheless, there were still some students who wrote short stories not based by the theme.

Creativity story development. In the 3rd meeting, the average percentage of students earned $62 \%$, and in the 4 th meeting, the score was $72 \%$. The development of the packaged story indeed still seemed difficult to develop, considering that not all students' literacy skills are the same and their accuracy to analyze short movies was used as a reference for developing stories.

Presentation of the storyline. In the 3rd meeting, the average percentage of students earned $68 \%$, and in the 4 th meeting, the score was $79 \%$. In presenting the storyline, most of them were mostly still illogical, this is because students have not developed the process to develop a story climax, hence their story tended to quickly ends. 
Muhammad Rizal Fauzi \& D. Fadly Pratama, Elementary Teacher Education Students' Short Story...

Presentation of characters. In the 3rd meeting, the average percentage of students earned $93 \%$, and in the 4th meeting, the score was $96 \%$. Nearly most students have understood the their character, this has an impact on the results of short moviemaking activities that directly involve students as actors.

Presentation of setting/place. In the 3rd meeting, the average percentage of students earned $88 \%$, and in the 4 th meeting, the score was $90 \%$. The setting of the place has been understood and used in their short stories. However, it was not accompanied by a cultural background as an addition to the artistic impression and imagination/fantasy for the reader.

The author's perspective. In the 3rd meeting, the average percentage of students earned $62 \%$, and in the 4 th meeting, the score increased to $68 \%$.Seen from the extrinsic element, most students still did not have a unique perspective in writing any short stories, because this is not easy to do for ordinary writers.

Selection of short story diction. In the 3rd meeting, the average percentage of students earned $63 \%$, and in the 4 th meeting, the score was $69 \%$. Choosing appropriate diction for elementary school children's reading is not easy. They still used words, phrases, and sentences that are considered to be incompatible with the readability composition of elementary school students.

Suitability of the title with the theme. In the 3rd meeting, the average percentage of students earned $81 \%$, and in the 4 th meeting, the score was $89 \%$. Determining a title that matches the theme of the short story was easy for students, but most of them have not been able to determine a unique title that can attract the attention of readers.

Spelling of the short story. In the 3rd meeting, the average percentage of students earned $57 \%$, and at the 4 th meeting, the score was $64 \%$. Some students still ignored the use of effective sentences, so that there are still many errors in sentence interpretation, ambiguity, and reading suitability.

Use of punctuation. In the 3rd meeting, the average percentage of students earned $69 \%$, and at the 4th meeting, the score was $73 \%$. Errors in punctuation were found in conversation and sentence punctuation exclamation.

\section{Short Story Writing Skills Questionnaire of Elementary Teacher Education Students through Short Movie Making Activities}

The questionnaire obtained from elementary teacher education students as respondents is a data statement about the skill to write short stories to students through short moviemaking activities. The following is the acquisition data of the questionnaire results filled out online: 
Table 3. Elementary Teacher Education Students' Questionnaire Results of Short Story Writing Activities through Short Movie Making Activities

\begin{tabular}{|c|c|c|c|c|c|}
\hline No & Statement & SA & A & $\mathrm{D}$ & SD \\
\hline 1 & $\begin{array}{l}\text { I understand the meaning of short stories through study } \\
\text { with lecturers. }\end{array}$ & 21.2 & 76.8 & 2 & 0 \\
\hline 2 & $\begin{array}{l}\text { I understand the elements of short stories through the } \\
\text { results of reading journal literature and the like. }\end{array}$ & 17.2 & 77.8 & 5 & 0 \\
\hline 3 & I prefer short stories with fictional texts. & 38.4 & 55.6 & 6 & 0 \\
\hline 4 & I prefer short stories with non-fiction texts. & 14.1 & 58.6 & 25.3 & 2 \\
\hline 5 & $\begin{array}{l}\text { I quickly understood the structure of short stories } \\
\text { through the media of short movies. }\end{array}$ & 29.3 & 60.6 & 8.1 & 2 \\
\hline 6 & $\begin{array}{l}\text { I feel happy when observing the short movie storyline as } \\
\text { material for writing short stories. }\end{array}$ & 28.3 & 66.7 & 4 & 1 \\
\hline 7 & $\begin{array}{l}\text { I got an idea / idea to make a short story after } \\
\text { watching a short movie. }\end{array}$ & 31.3 & 60.6 & 7 & 1 \\
\hline 8 & $\begin{array}{l}\text { I gained imagination to write short stories after } \\
\text { watching a short movie. }\end{array}$ & 28.3 & 63.6 & 7 & 1 \\
\hline 9 & I can make a short story after watching a short movie. & 24.2 & 64.6 & 10.1 & 1 \\
\hline 10 & $\begin{array}{l}\text { I easily understand the short story after watching a short } \\
\text { movie. }\end{array}$ & 21.2 & 67.7 & 10.1 & 1 \\
\hline 11 & $\begin{array}{l}\text { I can determine the character / character in the short } \\
\text { story. }\end{array}$ & 31.3 & 64.6 & 4 & 0 \\
\hline 12 & $\begin{array}{l}\text { I can use words / diction easily in writing short stories } \\
\text { after watching a short movie. }\end{array}$ & 13.1 & 68.7 & 16.2 & 1 \\
\hline 13 & $\begin{array}{l}\text { I can determine the grammar used in the short story } \\
\text { according to PUEBI / EYD after watching a short movie. }\end{array}$ & 7.1 & 67.7 & 22.2 & 3 \\
\hline 14 & $\begin{array}{l}\text { I easily write a message on a short story after watching } \\
\text { a short movie. }\end{array}$ & 16.2 & 78.8 & 3 & 2 \\
\hline & Average Percentage & $22.9 \%$ & $66.6 \%$ & $9.3 \%$ & $1.1 \%$ \\
\hline
\end{tabular}

Note: $S A=$ Strongly Agree; $A=$ Agree; $D=$ Disagree; $S D=$ Strongly Disagree

The questionnaire in Table 3 is a statement of students about the process of making short stories through short moviemaking. These statements were adjusted to the composition of the indicator which refers to the skills to write short stories made through short moviemaking. The results of the questionnaire showed that $22.9 \%$ of the students stated strongly agree, $66.6 \%$ of students stated agreed, $9.3 \%$ stated disagreed, and $1.1 \%$ strongly disagreed with short story learning conducted through short moviemaking activities by analyzing short story elements from the short movies of each student group.

\section{DISCUSSION}

\section{Short Story Writing Skills of Elementary Teacher Education Students through Short Movie Activities}

Following is the authors' elaboration of the results obtained by integrating and comparing the findings with the literature and previous studies) and relevant research results through the indicators of short story writing and the scope of this research. 
Muhammad Rizal Fauzi \& D. Fadly Pratama, Elementary Teacher Education Students' Short Story...

According to Nurgiyantoro (2013), Göçen (2019), and Kervin et al., (2017), the elements in the short story are a breakdown of the short story indicators which are intrinsic elements consisting of themes, titles, plot, characters, character, setting/place, climax, anticlimax, and message. Meanwhile, the extrinsic element is a character or perspective of an author of the storyline that has been made.

The suitability of the contents of the story with the theme increased. The results of data analysis from three instruments showed the similar same results on average. The data obtained from observations, tests, and questionnaires in the first meeting showed students' lacking skills to present the contents of the story by the theme because they did not understand the determination of main ideas, hence their ideas were developed very typical. As revealed by Rodríguez (2017), the key to understanding in reading can be obtained when the reader can determine the ideas, so that when he rewrites, he will understand how to develop explanatory ideas that fit the theme determined.

Presentation of short storylines. The students' skills to present short storylines was still not creative, in which the $63 \%$ of indicators implementation in meetings 1-3 indicated that storyline processing skills were still not appropriate. However, in the last meeting, the test results showed an average of $73.5 \%$ showing that the students were already skilled in developing the storyline. The complexity of short story writing is on designing the composition in a structured manner, so it is not common for students to have problems in writing short stories (Mongar \& Chalermnirundorn, 2020).

Creativity story development. It is undeniable that in the aspect of story development students still have considerable obstacles, considering the short stories developed are stories for children, so the process of story processing is considered rigid for some students. The similar idea is presented by Dewi (2016) states that they have interest in adult reading and writing story because that phase exists in the age they experience.

Viewing angle. The viewpoint becomes an extrinsic part that is significant in writing the short story (Liao, 2020), which leads to a short story that is distinctive and characterized. In this study the extrinsic element in the form of the perspective of each writer was still impressed amateur, considering that most students rarely write short stories, so that the characteristics of writing and the delivery of ideas could not be detected optimally.

Selection of diction. The diction used in most of the students' short stories was still not smooth, meaning that the diction use and position applied to elementary students' short stories were not appropriate, such as the use of sentences in communication that language is still not allowed in elementary students' reading. This is certainly still reasonable, arguing that students are not accustomed to writing, and aspects of their experience are no longer in the child's 
age phase. This reasoning is by the diction theory explained by Adam (2015), diction is the choice of words that represent thoughts and feelings to be conveyed both in the form of writing and words.

Use of spelling and punctuation. Spelling using PUEBI is important that builds structure in each writing. Silby \& Watts, (2015), explained that spelling in written language with verbal language has a different form, since the spelling in the written language must be formally designed, whereas in verbal language generally, the use of spelling is not involved because of the many mixed factors of the first language. The interesting finding is that they were still inconsistent in using formal and informal spelling and they did pay attention to the correct spelling. The mistake of each writer in designing short stories is that they are impressed to use free language, with the reason to maintain the originality of writing to be able to convey the message in totality (Chen, S., \& Zhou, 2010). Although in the writing of fantasy a writer should keep the correct spelling consistency and the meaning contained in the text can be conveyed according to the rules of the reader.

Based on the explanation above, short movies used as learning media to write short story leads to a more interactive language, so that it can effectively help students easily imagine and apply it to written language. In line with this, Hameed (2016) stated that "a visual media in the form of a movie provides an opportunity for a total immersion experience that is impossible to simulate in an environment. Audio visual aspects in movie media have an influence on students' emotional intelligence in learning. The dynamics of the conversation are well covered by the movie and it is a situation that is lost in the classroom setting. Thus, students see visual support such as facial expressions and gestures simultaneously. These visual cues serve as support for understanding the message and at the same time provide focus of attention".

\section{The Effectiveness Short Movie in Creative Writing Learning}

The authors note that basically in this study two aspects influence the short movie media on the elementary teacher education students' skills to write short stories about that distinguish them from other studies, including: First, visual \& audio. The movie becomes one of the visual media that is very effective in learning activities because students are invited to watch a story or an event that occurs immediately, so learning to write short stories can be effectively understood by every student (Liao, 2020). The similar thing is presented by Schneider et al., (2019)on media selection for the effectiveness of learning, in which the nature of instructional media should be able to be a role that simplifies the theory so that it can be understood by students. 
Muhammad Rizal Fauzi \& D. Fadly Pratama, Elementary Teacher Education Students' Short Story...

Secondly, experience. The experience of students making short movies has implications on the students' understanding about the elements of the story. Thus, they can easily design the structure/materials that must be prepared in writing short stories. This is in line with the research of Agustina et al. (2015) about the use of short movies to improve short story writing skills, the results of the study showed that in only two research cycles students were able to understand the concept of writing short stories by the indicators. Furthermore, the research of Csizer \& Kontra (2020), discusses improving writing skills through animated movie media, the results of their research explain the high enthusiasm of students for narrative writing skills because the students experienced new media and ways that were rarely used before. The experience (learning) process that distinguishes from previous research, that this research was conducted on students and they are not limited to observing short movies that already exist, but they are directly involved in making movies as well as taking the essence of movie experience to be used as knowledge in designing short stories. This idea is the one who can distinguish from other research.

A series of literature that explains short story writing skills always explain a complexity, considering writing short stories is an activity that requires multi-skill in a writer, ranging from connecting between experience and theory, analyzing, synthesis, to conclude what has been studied (Csizér \& Kontra, 2020; Lam, 2020). Writing short stories is the same as writing in general, in meaning to communicate ideas fluently and effectively and transferring emotions, thoughts, desires, and hopes through non-verbal language (writing). However, what distinguishes ordinary writing from short story writing is a high level of skill to convey ideas with narrative style told in sequence through a series of events, so writing short stories is part of the literary product presented to the reader through a fairly complex writing process (Chen, S., \& Zhou, 2010). However, that does not mean writing short stories are difficult to do. Writing is a process that requires a long process in line with experience, the more stages of writing experience are carried out the better the quality of the writing made (Rodríguez, 2017).

From this series of research, the authors can conclude that the writing skills of students in tertiary institutions become a remark in fulfilling the scientific indicators of the empirical process, because the written process must pass through the stages of experience that give an impression, so as to increase student understanding in writing. Therefore, the implementation of innovative media in this research is one of the keys to improving students' writing competence, one of which is through the short movie production process followed by students' short story writing. In addition to improving writing skills, students can also improve their empathy for 21 st century skills, one of their decision-making attitudes, problems, being able to speak in public, and become a holistic and transformative assessment (Perry, 2018). 


\section{CONCLUSION}

The process of learning to write short stories through short movie making activities obtained from observations shows the achievement of skill according to the indicators of writing short stories, starting from the process of observing short movie elements, analyzing movie components to design short stories, to making short stories at each meeting. The use of short movies can effectively improve students' skills to write short stories. It is seen based on the scores obtained based on the results of short story writing tests. Also, students were not only involved in the process of writing short stories but were directly involved in playing characters in short movies, so that they were able to complete the potential to write short stories according to the indicators.

There is the enthusiasm of students in participating in short story writing learning, this is evidenced by the high percentage of statements agreeing if learning to write a short story through short moviemaking activities is attractive. The increase in short story writing is not the main benchmark in this study. However, the students have reached the indicator of writing a short story consisting of (1) the suitability of the contents of the story with the theme; (2) creativity in story development; (3) presentation of storylines; (4) character presentation; (5) character presentation; (6) presentation of setting/place; (7) author's perspective; (8) short story selection; (9) the suitability of the title with the theme; and (10) spelling of reads and the use of punctuation.

\section{REFERENCES}

Abidin, Y. (2015). Multyliteracy Learning. PT. Refika Aditama.

Adam. (2015). Developing EFL Learners' Narrative Writing through Using Short Stories- The Case of Al-Baha Universiy Students. European Journal of English Language and Literature Studies, 3(4), 1-8. https://www.eajournals.org/journals/european-journal-of-englishlanguage-and-literature-studies-ejells/vol-3-issue-4september-2015/developing-efllearners-narrative-writing-through-using-short-stories-the-case-of-al-baha-universiystudents.

Agustina, K. A., Artawan, G., \& Astika, M. (2015). Penggunaan Movie Pendek Untuk Meningkatkan Kemampuan Menulis Cerpen Siswa Kelas IX A SMP Negeri 1 Gerokgak [The Use of Short Movie to Improve The Ability to Write Stories of Class IX A Students of Smp Negeri 1 Gerokgak]. 1-12. https://doi.org/http://dx.doi.org/10.23887/jjpbs.v3i1.6255.

Arikunto, S. (2013). Research Procedure on a Practice Approach. Rineka Cipta.

Bachri, B. (2010). Meyakinkan Validitas Data Melalui Triangulasi Pada Penelitian Kualitatif [Assuring Data Validity Through Triangulation in Qualitative Research]. Jurnal Teknologi Pendidikan, 10, 46-62. http://ejournal.unesa.ac.id/index.php/jurnal_tp/article/view/5006.

Beiler, I. R., \& Dewilde, J. (2020). Translation as Translingual Writing Practice in English as an Additional Language. Modern Language Journal, 104(3), 533-549. https://doi.org/10.1111/modl.12660.

Blasco, P. G., Moreto, G., Blasco, M. G., Levites, M. R., \& Janaudis, M. A. (2015). Education through Movies: Improving teaching skills and fostering reflection among students and teachers. Journal for Learning through the Arts: A Research Journal on Arts Integration in Schools and Communities, 11 (1). https://doi.org/https://doi.org/10.21977/D911122357. 
Muhammad Rizal Fauzi \& D. Fadly Pratama, Elementary Teacher Education Students' Short Story...

Chaya, P., \& Inpin, B. (2020). Effects of Integrating Movie-Based Mobile Learning Instruction for Enhancing Thai University Students' Speaking Skills and Intercultural Communicative $\begin{array}{llll}\text { Competence. English Language Teaching, } 27 . & \text { 13(7), }\end{array}$ https://doi.org/10.5539/elt.v13n7p27.

Chen, S., \& Zhou, J. (2010). Creative writing strategies of young children: Evidence from a study of Chinese emergent writing. Thinking Skills and Creativity, 5, 138-149.

Creswell, J. (2014). Research Design Design (Pendekatan Kualitatif, Kuantitatif dan Mixed). Pustaka Pelajar.

Csizér, K., \& Kontra, E. H. (2020). Foreign Language Learning Characteristics of Deaf and Severely Hard-of-Hearing Students. Modern Language Journal, 104(1), 233-249. https://doi.org/10.1111/modl.12630.

Derry, S., Sherin, M., \& Sherin, B. (2014). Multimedia Learning with Video. The Cambridge Handbook of Multimedia Learning, 10(1017), 785-812. https://doi.org/https://doi.org/10.1017/CBO9781139547369.038.

Dewi, N. P. F. D. dkk. (2016). Kesulitan Belajar Keterampilan Menulis Cerita Pendek Siswa Kelas IX C SMP Negeri 3 Singaraja Tahun Pelajaran 2016/2017 [Learning Difficulties Writing Short Story Skills for Ixc Grade Students of SMP Negeri 3 Singaraja, 2016 Academic Year]. EJournal Prodi Pendidikan Bahasa Dan Sastra Indonesia, Undiksha, Vol: 5(1). https://doi.org/http://dx.doi.org/10.23887/jjpbs.v5i3.8619.

Eng, C. M., Godwin, K. E., \& Fisher, A. V. (2020). Keep it simple: streamlining book illustrations improves attention and comprehension in beginning readers. Npj Science of Learning, 5(1). https://doi.org/10.1038/s41539-020-00073-5.

Ezza, E. S., Alhuqail, E., \& Elhussain, S. (2019). Technology-based instructional intervention into an EFL writing classroom. Cypriot Journal of Educational Sciences, 14(4), 507-519. https://doi.org/10.18844/cjes.v11i4.3904.

Feeney, T., \& Gajaseni, C. (2020). Effectiveness of reading short stories to develop intercultural communicative competence among Thai students at an international school. LEARN Journal: Language Education and Acquisition Research Network, 13(2), 126-141. https://so04.tci-thaijo.org/index.php/LEARN/issue/view/16657.

Frith, U. (2020). Teaching in 2020: The Empact of Neuroscience. Journal Education for Teaching, 31, 289-291. https://doi.org/https://doi.org/10.1080/02607470500280118.

Galante, A. (2015). Developing EAL Learners' Intercultural Sensitivity Through a Digital Literacy Project. TESL Canada Journal, 32(1), 53. https://doi.org/10.18806/tesl.v32i1.1199.

Göçen, G. (2019). The effect of creative writing activities on elementary school students ' creative writing achievement, writing attitude and motivation *. JOURNAL OF LANGUAGE AND LINGUISTIC STUDIES, 15(3), 1032-1044. https://doi.org/10.17263/jlls.631547.

Hameed, P. (2016). Short Movies in the EFL Classroom: Creating Resources for Teachers and Learners. International Journal of Applied Linguistics \& English Literature, 5(2). https://doi.org/10.7575/aiac.ijalel.v.5n.2p.215.

Jayani, D. H. (2019). How Many Internet Users in Indonesia? https://databoks.katadata.co.id/datapublish/2019/09/09/berapa-pengguna-internet-diindonesia\#: :text=Data Statista 2019 menunjukkan pengguna,\%25 pada periode 20182023.

Kabadayi, L. (2012). The Role of Short Movie in Education. Procedia - Social and Behavioral Sciences, 47, 316-320. https://doi.org/10.1016/j.sbspro.2012.06.657.

Kartika, A.R. R., Susilo, S., \& Natsir, M. (2018). The Effect of Silent Short Movie on EFL Writing Achievement of Vocational High School Students. Proceedings of the 2017 International Conference on Education and Technology (2017 ICEduTech), 7(2), 168-179. 
https://doi.org/10.2991/icedutech-17.2018.4.

Kervin, L., Comber, B., \& Woods, A. (2017). Toward a Sociomaterial Understanding of Writing Experiences Incorporating Digital Technology in an Early Childhood Classroom. Literacy Research: Theory, Method, and Practice, 66(1), 183-197. https://doi.org/10.1177/2381336917718522.

Kim, S. (2016). The effects of multimodality through storytelling using various movie clips. CALL Communities and Culture - Short Papers from EUROCALL 2016, 2016(2016), 221-224. https://doi.org/10.14705/rpnet.2016.eurocall2016.565.

Lam, R. (2020). Investigating Assessment as Learning in Second Language Writing: A Qualitative Research Perspective. International Journal of Qualitative Methods, 19, 1-10. https://doi.org/10.1177/1609406920938572.

Liao, W. (2020). Using Collaborative Video-Cued Narratives to Study Professional Learning: A Reflective Analysis. International Journal of Qualitative Methods, 19, 1-13. https://doi.org/10.1177/1609406920949335.

Linda, W. (2017). Keterampilan Menulis Kreatif Cerpen Menggunakan Media Audio Siswa Kelas XII SMAN 1 Kecamatan Payakumbuh [Short Story Creative Writing Skills Using Audio Media Students Class Xii Sman 1, Payakumbuh District]. Bahastra, 37(1), 89. https://doi.org/10.26555/bahastra.v37i1.5641.

Mongar, D. S., \& Chalermnirundorn, N. (2020). The Use of Animated Movies to Enhance Narrative Writing Skills of Grade Six Bhutanese. Thai Journal Online, 245-262. https://so01.tci-thaijo.org/index.php/AJPU/article/view/223267.

Moore, B., Boardman, A. G., Smith, C., \& Ferrell, A. (2019). Enhancing collaborative group processes to promote academic literacy and content learning for diverse learners through video reflection. SAGE Open, 9(3). https://doi.org/10.1177/2158244019861480.

Nurgiyantoro, B. (2013). Assessment of Language Based Learning. BPEFE-Yogyakarta.

Patrick, M. (2019). Free Voluntary Reading and Comprehensible Input. Journal of Classics Teaching, 20(39), 78-82. https://doi.org/10.1017/s2058631019000126.

Perry, M. S. (2018). 21st Century Skills through Movie Production in Tertiary Education: A transformative assessment in a literature and media course. $3 \mathrm{~L}$ : Language, Linguistics, Literature, 24(4), 214-232. https://doi.org/10.17576/3L-2018-2404-16.

Persadha, D. A. K. (2016). Studi Kompetensi Kemampuan Menulis di Kalangan Mahasiswa [Writing Ability Competency Study Among Students]. Muaddib: Education and Islamic Studies, 6(1), 1. https://doi.org/10.24269/muaddib.v6n1.2016.1-20.

Purba, R. (2018). Improving the Achievement on Writing Narrative Text through Discussion Starter Story Technique. Advances in Language and Literary Studies, c, 0-3. https://www.journals.aiac.org.au/index.php/alls/article/view/4074.

Redifer, J. L., Bae, C. L., \& DeBusk-Lane, M. (2019). Implicit Theories, Working Memory, and Cognitive Load: Impacts on Creative Thinking. SAGE Open, 9(1). https://doi.org/10.1177/2158244019835919.

Rezaei, S., \& Naghibian, M. (2018). Developing intercultural communicative competence through short stories: A qualitative inquiry. Iranian Journal of Language Teaching Research, 6(2), 77-96. https://doi.org/10.30466/IJLTR.2018.120561.

Rodríguez, G. L. (2017). Students' language skills development through short stories. Ikala, 22(1), 103-1 18. https://doi.org/10.17533/udea.ikala.v22n01a07.

Schneider, J., Hazel, S., Morgner, C., \& Dening, T. O. M. (2019). Facilitation of positive social interaction through visual art in dementia: A case study using video-analysis. Ageing and Society, 39(8), 1731-1751. https://doi.org/10.1017/S0144686X1800020X.

Silby, A., \& Watts, M. (2015). Making the tacit explicit: Children's strategies for classroom 
Muhammad Rizal Fauzi \& D. Fadly Pratama, Elementary Teacher Education Students' Short Story...

writing. British Educational Research Journal, $41(5), \quad 801-819$. https://doi.org/10.1002/berj.3176.

Simanungkalit, E \& Sembiring, M. (2019). Penerapan Model Pembelajaran Peta Konsep (Mind Mapping) Terhadap Kemampuan Menulis Peta Karakter Anak Berbasis Karakter Oleh Mahasiswa Departemen PGSD DIK EKS H 2017 [Implementation of a Concept Map Learning Model (Mind Mapping) To The Ability To Write Ch. National Seminar on Basic Education of Medan State University, 132-148. https://jurnal.unimed.ac.id/2012/index.php/snpu/article/view/16115.

Sugiyono. (2015). Educational Research Methods with Quantitative Approaches, Qualitative and $1 R$ \& D. Alfabeta.

Yusuf, O. (2018). Indonesian Internet Users World Number Six. https://kominfo.go.id/content/detail/4286/pengguna-internet-indonesia-nomor-enamdunia/0/sorotan_media. 